\title{
An Empirical Study on the Impact of Private Equity Investment on GEM Listed Companies
}

\author{
Yuanyuan Wang ${ }^{1,2, a}$ and Jianhua Luo ${ }^{1, b, *}$ \\ ${ }^{1}$ Business College, Central South University, Hunan 410083, China \\ ${ }^{2}$ Hunan province highway administration Changsha, Hunan 410022, China \\ auanyuanwang2007@163.com, ${ }^{b}$ ljh9098@126.com
}

\begin{abstract}
Growth enterprise market (GEM) has been introduced to China for more the ten years. This research aims to study the factors influencing the IPO underpricing rate related to private equity investment. From October 30, 2011 to December 31, 2012, companies listed on the Shenzhen Stock Exchange GEM were selected as research samples. Correlation and multiple regression methods were used in the data analysis. The results indicate that the factors influence the IPO underpricing rate including the enterprises in secondary market. The investors of the GEM also lead to the high underpricing rate of IPO.
\end{abstract}

Keywords: private equity: GEM market; IPO underpricing rate; market performance

\section{Introduction}

With the legalization of the domestic limited partnership and the introduction of Growth Enterprise Market (GEM), China's private equity market develops rapidly in the past ten years. The impact of private equity investment on the investment Enterprise Inc. governance is also increasingly widespread concern.

Private equity (PE) institutions usually with limited partnership fund for nonlisted companies of equity investment, and in the future through listing, mergers and acquisitions or management layer of the repurchase of the sale of shares to profit [1]. According to the definition of the American Venture Capital Association (NVCA), private equity investment, including venture capital fund (Capital Venture, referred to as VC), mergers and acquisitions Fund (Buyout), Mezzanine (Investment), the fund's Fund (FOF), etc., [2]. At present, the development of the most scale of foreign mergers and acquisitions fund and venture capital fund. The merger and acquisition funds often appear in the MBO, MBI, the selected objects are mostly mature enterprises, through the acquisition of gain control of target enterprise, such as Carlyle, KKR and Blackstone [3]; The venture capital fund is often in the form of equity investment venture, after the investment management to make its value, and finally through the IPO and other forms of exit, such as Sequoia, IDG and so on. Although the study of domestic scholars generally in the late stage of equity investment as PE, but due to PE, VC blurred boundaries, on specific projects, it is difficult to identify the amount of investment, investment stage, industry attributes, etc., so this classification in the current equity investment market is not significant [4].

In May 1, 2012, the official implementation of the gem delisting system, a lot of comments that this will make the venture capital market ushered in a very good cleans [5]. The implementation of the delisting mechanism, making the valuation of the GEM companies to reduce the extent of the actual value, that is, the company's

${ }^{*}$ Corresponding Author 
valuation will be more close to the real value of the enterprise, the phenomenon of high valuation will be suppressed, the part of the hope that through the high valuation of the IPO out of the private equity investment institutions to achieve excess returns, this way to achieve the possibility of reducing [6]. Under the superior rules of the game, a number of firms will continue to stay in this market, and a large number of firms will leave the stage, and before and after the launch of the GEM companies, the investment will pay a certain price before the high valuation. And with the withdrawal of private equity investment, gem market hot speculation situation will be some control, from a certain extent inhibited the production of "three high" phenomenon [7].

Since the formal establishment of the gem, many scholars carried on a research mainly concentrated in gem regulatory requirements, risk prevention and exit mechanism, rarely of in-depth study of the private equity investment impact on the GEM companies. This paper makes a quantitative study on the impact of private equity investment on GEM listed companies through empirical research, which is of great practical significance.

\section{Research Method Design}

\subsection{Sample Source}

The sample of this study is on October 30, 2011 (the gem opening day) to December 31, 2012 listed on the Shenzhen Stock Exchange gem 152 enterprises as the research sample. The reason why only chooses to the end of December 31, 2012 listed companies, is because this paper intends to study the value of the enterprise after IPO enterprise value, combined with private equity investment in 1-2 years after the general situation of IP0, and write the time of this paper, select the end of 2013 data as the basis for enterprise value analysis. According to the need of the research, the author has done a lot of data collection and sorting work, and the specific data sources are shown in Table 1 .

Table 1. Data Sources

\begin{tabular}{ccc}
\hline & Type & Data sources \\
Database & Taian database \\
Wind cast net station & $\begin{array}{c}\text { Investment in China, Zero2IPO Research Center, } \\
\text { Investment sector and other network stations. }\end{array}$ \\
Website & $\begin{array}{c}\text { Finance and } \\
\text { Economics website }\end{array}$ & Hexun.com, Sina Finance and economics, etc., \\
\hline
\end{tabular}

\subsection{Hypothesis Proposed}

Domestic research on VC/PE is mainly focused on the listing Corporation, and through the study of small and medium enterprise board of Shenzhen from 2004 to 2007 data and the mean difference, Cuiyi, Zhang Ze Qin, Yang skimmer (2008) have obtained venture capital (VC) underpricing support firm PO higher conclusion. For the impact of private equity investment on IPO, the conclusions of domestic and foreign scholars' research are not the same. But the reasons for the results of the study are mainly due to two aspects: one is that the certification regulatory role has been or has not been played, and the second is whether the presence of grandstanding model in the chase profit effect.

The main idea of the certification regulatory model is: VC/PE institutions have the ability to identify the project, so VC/PE holdings will be used as the IPO company's certification, which is to transfer the company has a good future signal to 
the public, in addition, $\mathrm{VC} / \mathrm{PE}$ institutions in order to achieve the purpose of profit, but also better play to the role of the supervision of the investment company, to achieve value-added enterprise value [8]. According to the theory, $\mathrm{VC} / \mathrm{PK}$ institutions can better complete the role of the third party certification for two main reasons: first, because the VC/PE agency holds a stake in the company's boss, in the board of directors has seats, and has a long time with the enterprise close cooperation relationship, therefore, can be more clear understanding of enterprise information and real value[9]; In order to improve the enterprise value, risk investment institutions will be as much as possible to the operation of supervision company, value-added investment, also disguised to achieve certification. Therefore, in the role of certification regulation, the support of private equity investment will make the enterprise IPO underpricing degree reduced [10]. According to certification regulation theory, support enterprises of $\mathrm{VC} / \mathrm{PE}$ organization, high stake, private equity investment institutions to enterprise's certification supervision function, the more obvious, therefore, the enterprise IPO underpricing rate will be lower. Based on the above theory, in order to verify whether private equity for gem listed companies have certification regulation effect, this paper puts forward the following two to be empirically assumption [11]:

Assumption 1: Having VC/PE backed companies in the IPO underpricing rate is lower than the same day without VC / PE backed companies;

Assumption 2: The VC / PE stake higher, the lower GEM companies in the IPO underpricing day.

The model which the certification theory is corresponding to is the grandstanding model. And the model believes that under the demand of the fame and interest, the venture capital institutions will promote the investment companies listed as soon as possible, and in a nutshell, the investment institutions exist profit mentality. There are two main reasons: one of the reasons is that a good reputation is an effective way to attract investors, in order to attract more investors, VC/PE institutions will take a variety of means to improve their reputation, which also includes eager to prove their ability to the outside world. In this case, it will be the not mature companies on PO market. The second reason is that IPO is able to achieve the maximum return on the way to exit, and in order to obtain excess returns, VC/PE institutions will be listed as soon as possible to be invested enterprises to achieve exit. In the failure to play a regulatory role in the certification at the same time, this behavior of pushing the behavior of the GEM market will lead to poor performance of the market and IPO after operating results, and eventually, it will lead to a decline in the value of listed companies, affecting the value of the enterprise value added, which means that private equity investment in listed companies did not produce value-added effects. Based on the above model, this paper proposes the following two assumptions.

Assuming 3: in the IPO after the market performance the enterprise with VC/PE support is worse than no $\mathrm{VC} / \mathrm{PE}$ support enterprise;

\subsection{Research Methods}

In this paper, the empirical research method is designed as follows [12]:

The 152 companies are divided into VC/PE support and no VC/PE support two groups, the group is based on the former ten shareholders to see whether the disclosure of the pre listing prospectus, the criteria are: first, look at the top ten shareholders of listed companies, venture capital investment, or venture capital investment, is identified as the support of private equity investment; Second, if there is investment, science and technology investment and other words in the name of the shareholders, the Internet access to view 2009 China venture capital Yearbook appendix of the Chinese firm to confirm the directory. Through statistics, 152 
companies, there are 97 private equity investment support, 55 did not support private equity investment, private equity investment on the gem support rate of $64 \%$.

For assumption 1, the main method adopted mean analysis and multiple regression analysis; For assumption 2, this paper take multiple regression analysis, there will be private equity backed companies alone do multiple regression analysis; In addition, based on the integrity of the data, data to eliminate not full of 11 enterprises, hypotheses of selected data is 141 , which has 90 private equity backed enterprise, no private equity backed 51 Enterprises; All the data are analyzed by data analysis software Excel and SPSS17. 0.

\subsection{Selection of Variables}

Selection of dependent variables

In this paper, the study of the private equity investment of gem IPO underpricing rate. Therefore, selection for variable is enterprise IPO underpricing rate, widely used in the academic underpricing rate calculation method is: IPO underpricing rate $=($ the first day closing price - listing price $) /$ issue price listed on $\times 100 \%$.

Use a formula that is:

$Y=\frac{\left(P_{1}-P_{0}\right)}{P_{0}} \times 100 \%$.

The selection of independent variables and control variables

Domestic and foreign related research shows that influence enterprise IPO underpricing degree of price factors, this paper according to the former research and combined with the characteristics of gem screened the following possible factors affecting gem enterprise IPO underpricing rate, and the specific circumstances can see Table 2.

Table 2. The Factors Affecting the IPO Underpricing Rate of the Gem

Variable

Actual fund total amount of capital

First price

Net profit margin of the previous year

Debt ratio of the previous year

Net assets per share

First day city profit rate

First day rate of change

Success rate

Stock underwriting expense ratio
Explanation

Excessive issue size will dilute the degree of PO underpricing, so the total amount of funds raised and the underpricing rate is negatively correlated.

The higher the issue price, the less investor will be, the lower the degree of underpricing, and the lower the degree of underpricing are.

Reflect the financial situation of enterprises before PO.

On the first day of the city, the business of the table is now

The success rate is low; it shows the stock purchase more.

Underwriting fees / actual total funds rose. 
Actually raise the total funds: large issuance size will dilution of IPO underpricing degree, so the actual raising the total funds and underpricing rate was negative correlation. Starting price: the higher the offering price, investors will be less and less, underpricing degree is low [13]; a year ago net assets income rate: reflect the financial situation of the enterprises before the IPO; A year ago of assets and liabilities rate; issued prior to the net assets per share, listed on the first day of earnings rate: listed on the first day of the performance status; day turnover rate; success rate: success rate is lower that the stock purchase more; proportion of stock underwriting fees: underwriting fees / actually raised the total funds.

\subsection{Model Setting}

According to the definition and selection of explanatory variables, independent variables and control variables, establish the following two models [14]:

Hypothesis 1 test model:

$Y=\alpha+\beta_{1} * X_{1}+\beta_{3} * X_{3}+\beta_{4} * X_{4}+\beta_{5} * X_{5}+\beta_{6} * X_{6}+\varepsilon$.

Hypothesis 2 test model:

$Y=\alpha+\beta_{2} * X_{2}+\beta_{3} * X_{3}+\beta_{4} * X_{4}+\beta_{5} * X_{5}+\beta_{6} * X_{6}+\varepsilon$

Among them, $X_{3}, X_{4}, X_{5}, X_{6}$, representing the issue price, listed on the first day turnover rate, listed on the first day of the City surplus rate and market rate of assets and liabilities of a year ago, is constant and is residual. Model 1 used to verify whether private equity investment support of the GEM Listing enterprise IPO underpricing rate is significantly different, so $X_{1}$ is a dummy variable, the representative has no support for private equity investment; Model 2 is used for inspection of private equity investment stake underpricing rate impact on the GEM listed companies, so the shareholding ratio of the $\mathrm{X}_{2}$ represents the private equity investment institutions.

\section{Empirical Results and Analysis}

\subsection{Descriptive Statistic}

The author after collecting and related indexes of 141 companies will 2011 October 30, 2014 to December 31 in the GEM listing descriptive analysis. The results are as follows:

Table 3. Descriptive Statistics

\begin{tabular}{ccccccc}
\hline & $\mathrm{N}$ & Minimum & Maximum & $\begin{array}{c}\text { Mean } \\
\text { value }\end{array}$ & $\begin{array}{c}\text { Standard } \\
\text { deviation }\end{array}$ & Variance \\
$\begin{array}{c}\text { IPO underpricing } \\
\text { rate }\end{array}$ & 141 & -.0991 & 2.0973 & .5049 & .3944380 & .156 \\
$\begin{array}{c}\text { Issue price } \\
\text { Listed on the first } \\
\text { day turnover rate }\end{array}$ & 141 & 11.3000 & 110.0000 & 33.7598 & 16.8863 & 285.149 \\
$\begin{array}{c}\text { First day price } \\
\text { earnings ratio }\end{array}$ & 141 & .4710 & 138.4600 & 23.24834 & 34.2109 & 1170.385 \\
$\begin{array}{c}\text { Asset liability ratio } \\
\text { in the previous year }\end{array}$ & 141 & .0617 & .7027 & .385414 & .1350 & .018 \\
$\begin{array}{c}\text { VC/PE } \\
\text { shareholding ratio }\end{array}$ & 90 & .0125 & .4283 & .168046 & .1028 & .011 \\
\hline
\end{tabular}


On the table, we can see, in 141 GEM listed companies, IPO underpricing rate average $50.49 \%$, far more than developed countries mature market underpricing rate (generally $10 \%-20 \%$ ), and IPO underpricing rate gap is relatively large, maximum 209. 73\%, and the value is $9.91 \%$. It also illustrates the current characteristics of the GEM market in China: lack of maturity and stability; Average 75. $16 \%$ of the exchange rate that do pioneering work board the market is more active; VC/PE support 90 companies, VC/PE Institutions shareholding ratio is also relatively large differences, minimum is $1.25 \%$, while the maximum value was $42.83 \%, 16.8 \%$ of the average value also shows the higher shareholding ratio in $\mathrm{VC} / \mathrm{PH}$ mechanism.

\subsection{Hypothesis 1 Test}

Mean value analysis

First of all, the 153 samples were divided into two groups, VC/PE backed group and non $\mathrm{VC} / \mathrm{PE}$ support group, and according to the grouping within the group of enterprises mean were compared. The results are as follows:

Table 4. Comparison of Results

\begin{tabular}{cccc}
\hline Index & VC/PE support & No VC/PE support & Significance \\
IPO underpricing rate & 0.54 & 0.48 & 0.392 \\
issue price & 32.88 & 35.30 & 0.414 \\
Listed on the first day turnover & 0.73 & 0.78 & $0.03 * *$ \\
$\begin{array}{c}\text { rate } \\
\text { First day price earnings ratio }\end{array}$ & 0.22 & 0.26 & 0.555 \\
$\begin{array}{c}\text { Asset liability ratio in the } \\
\text { previous year }\end{array}$ & 0.39 & 0.38 & 0.925 \\
\hline
\end{tabular}

From the table we can see that listed on the first day turnover rate significantly less than 0.05 , in addition, other mean comparison results are not significant, that is, VC / PE support for GEM companies, on the day of the underpricing rate, the starting price, listed on the first day of earnings and a year ago of assets and liabilities rate of no significant difference, from the results we can draw the following conclusions:

Although the VC/PE backed companies listed on the day of underpricing rate value slightly higher than those without VC/PE support enterprises, but between the two groups did not show a significant difference, so there is no $\mathrm{VC} / \mathrm{PE}$ support for gem enterprises listed on the same day underpricing rate had no significant difference, that is, assumption 1 does not hold.

Multiple regression analysis

Based on the mean analysis, according to the test model was to do multiple regression analysis.

1) Correlation test

To examine the correlation between the variables in the model 1:

Table 5. Correlation Test

\begin{tabular}{ccccccc}
\hline Pearson correlation & $\begin{array}{c}\text { IPO } \\
\text { under } \\
\text { pricin } \\
\text { g rate }\end{array}$ & $\begin{array}{c}\text { Whether } \\
\text { there is PE }\end{array}$ & Issue price & $\begin{array}{c}\text { Listed on the } \\
\text { first day } \\
\text { turnover rate }\end{array}$ & $\begin{array}{c}\text { First day } \\
\text { price } \\
\text { earnings } \\
\text { ratio }\end{array}$ & $\begin{array}{c}\text { Asset liability } \\
\text { ratio in the } \\
\text { previous year }\end{array}$ \\
IPO underpricing rate & 1.000 & -073 & -.354 & .710 & -.191 & -.112 \\
Whether there is PE & -.073 & 1.000 & -060 & -.183 & -.050 & .008 \\
issue price & -.354 & -.060 & 1.000 & -.226 & .204 & -.149 \\
\hline
\end{tabular}




\begin{tabular}{ccccccc}
\hline $\begin{array}{c}\text { Listed on the first day } \\
\text { turnover rate }\end{array}$ & .710 & -183 & -.226 & 1.000 & .065 & -.053 \\
$\begin{array}{c}\text { First day price } \\
\text { earnings ratio }\end{array}$ & -.191 & -.050 & .204 & .065 & 1.000 & -.010 \\
$\begin{array}{c}\text { Asset liability ratio in } \\
\text { the previous year }\end{array}$ & -112 & .008 & -149 & -053 & .010 & 1.000 \\
\hline
\end{tabular}

From Table 3, we can see that the correlation test results and the comparison of the mean similar results, with or without VC/PE backed and IPO underpricing rate was very weak negative correlation (usually under the following range of decision variables of the related strength: strong correlation, with a correlation coefficient of 0.8 to 1.0 ; strong correlation coefficient: $0.6-0.8$; moderate: correlation coefficients 0.4-0.6; weakly correlated, with a correlation coefficient of 0.2-0.4; very weak relevant or no correlation: the correlation coefficient 0.0-0.2); Pearson correlation coefficient is only -0.073 , and the coefficients of correlation between the control variables and independent variables are in the allowed range $(<6)$. So, the model was test by auto correlation test.

2) Test of agreement

The goodness of fit test is shown in Table 6 .

Table 6. Test of Agreement

\begin{tabular}{ccccccc}
\hline Model & $\mathrm{R}$ & $\mathrm{R} 2$ & $\begin{array}{c}\text { Adjust } \\
\mathrm{R} 2\end{array}$ & $\begin{array}{c}\text { Standard error of } \\
\text { estimation }\end{array}$ & $\mathrm{F}$ & Sig.F \\
1 & $.771 \mathrm{a}$ & .594 & .579 & .2559425 & 39.501 & $.000 \mathrm{a}$
\end{tabular}

a. variables (constants), rate of assets and liabilities of a year ago, PE, listed on the first day of the price earnings ratio, listed on the first day turnover rate, log: the issue price.

Adjusted R2 was 0. 579. Regression equation is better, the F statistic significant. It is proved that the whole model of the explanatory variables explain is better.

3) Multiple linear regressions

According to the regression results, the regression equation was obtained:

$Y=-0.388+0.027 * \mathrm{X}_{1}-0.153 * \mathrm{X}_{3}+2.087 * \mathrm{X}_{4}-0.002 * \mathrm{X}_{5}-0.302 \mathrm{X}_{6}+\varepsilon$

Table 7. Significance Test of Regression Coefficient

\begin{tabular}{|c|c|c|c|c|c|}
\hline & \multicolumn{2}{|c|}{ Non standardized coefficient } & \multirow{2}{*}{$\begin{array}{c}\text { Standardized } \\
\text { coefficient } \\
\text { trial version }\end{array}$} & \multirow[t]{2}{*}{$\mathrm{t}$} & \multirow[t]{2}{*}{ Sig. } \\
\hline & $\mathrm{B}$ & standard error & & & \\
\hline Constant & -.388 & .273 & & -1.423 & .157 \\
\hline \multirow{2}{*}{$\begin{array}{l}\text { Whether there is PE } \\
\text { Logarithm: issue } \\
\text { price }\end{array}$} & .027 & .046 & .033 & .593 & .554 \\
\hline & -.153 & .052 & -.172 & -2.918 & $.004 * * *$ \\
\hline $\begin{array}{l}\text { Listed on the first } \\
\text { day turnover rate }\end{array}$ & 2.087 & .177 & .684 & 11.777 & $.000 * * *$ \\
\hline $\begin{array}{l}\text { Listed first earnings } \\
\text { ratio }\end{array}$ & -.002 & .001 & -.200 & -3.541 & $.001 * * *$ \\
\hline $\begin{array}{l}\text { Asset liability ratio } \\
\text { in the previous year }\end{array}$ & -.302 & .163 & -.103 & -1.854 & $.066^{*}$ \\
\hline \multicolumn{6}{|c|}{$\begin{array}{l}\text { a. dependent variable: IPO underpricing rate } \\
\text { ectively, expressed significant levels of } p<0.01,001<p<0.05,0 \\
\qquad 05<p<0,1 .\end{array}$} \\
\hline
\end{tabular}


More than multiple regression results show that, listed on the first day turnover rate increases by $1 \%$ each, IPO underpricing rate will increase $208.7 \%$, indicating that the higher the level of activity in the secondary market, greater impact on the underpricing rate, issue price for every $1 \%$ increase in the number, IPO underpricing rate will reduce $15.3 \%$, listed on the first day of the city of earnings ratio for every $1 \%$ increase, IPO underpricing rate will be reduced by $2 \%$, a year ago, assets and liabilities rate did not increase $1 \%$, IPO underpricing rate decreased $3.02 \%$, in line with expectations of forecasting results and the four on IPO underpricing rate significantly affected; And there is no VC/PE support of the regression coefficient table, there are VC/PK support for enterprise IPO underpricing rate is higher, but this correlation is not significant, which is consistent with the results of the previous mean analysis and correlation test results, assuming that 1 does not set up.

\subsection{Hypothesis 2 Test}

Hypothesis 1, is not established, it is proved that $\mathrm{VC} / \mathrm{PE}$ support and no significant difference in the rate of IP0, that is, VC/PE support or not cannot verify whether private equity investment institutions play a certification role, the author through another way: there will be 90 companies VC/PK support separately extracted, based on the assumption of theoretical basis, the proportion of VC/PE institutions to add and finishing, combined with model 2 multiple regression analysis, in order to verify the role of private equity investment.

Table 8. Significance Test of Regression Coefficient

\begin{tabular}{|c|c|c|c|c|c|}
\hline & \multicolumn{2}{|c|}{$\begin{array}{l}\text { Non standardized } \\
\text { coefficient }\end{array}$} & \multirow{2}{*}{$\begin{array}{l}\text { Standardized } \\
\text { coefficient } \\
\text { trial version }\end{array}$} & \multirow[t]{2}{*}{$\mathrm{t}$} & \multirow[t]{2}{*}{ Sig. } \\
\hline & B & standard error & & & \\
\hline Constant & .148 & .357 & & 415 & 680 \\
\hline Whether there is PE & .559 & .306 & .141 & 1.827 & $.071 *$ \\
\hline \multirow{2}{*}{$\begin{array}{l}\text { Logarithm: issue price } \\
\text { Listed on the first day } \\
\text { turnover rate }\end{array}$} & -.205 & .073 & -.220 & -2.791 & $.006^{* * *}$ \\
\hline & 1. 136 & .241 & .395 & 4. 703 & $.000 * * *$ \\
\hline $\begin{array}{l}\text { Listed first earnings } \\
\text { ratio }\end{array}$ & .368 & .110 & .277 & 3.346 & $.001 * * *$ \\
\hline $\begin{array}{c}\text { Asset liability ratio in } \\
\text { the previous year }\end{array}$ & -.637 & .220 & -.211 & -2.896 & $.005 * * *$ \\
\hline b. $* * *, * * *$, respec & endent & $\begin{array}{l}\text { iable: IPO unde } \\
\text { d significant les } \\
05<p<0,1 \text {. }\end{array}$ & $\begin{array}{l}\text { oricing rate } \\
\text { ls of } p<0.01 \text {, }\end{array}$ & $01<\mathrm{p}<0$ & 05,0 \\
\hline
\end{tabular}

Table 9. Three Scheme Comparing

\begin{tabular}{lllrrrr}
\hline Model & $\mathrm{R}$ & $\mathrm{R} 2$ & $\begin{array}{c}\text { Adjust } \\
\mathrm{R} 2\end{array}$ & Standard error of estimation & F & Sig.F \\
1 & .754 & .568 & .542 & .2754642 & 22.099 & $.000 \mathrm{a}$
\end{tabular}

a. variables (constants), rate of assets and liabilities of a year ago, PE, listed on the first day of the price earnings ratio, listed on the first day turnover rate, log: the issue price.

According to the goodness of fit test results can be seen, the model of the R party is 0.568 , the adjusted $R$ square is 0.542 , the regression equation is better, the $F$ statistic is significant, and the whole model is proved to be explained by the explanatory variables. 
The regression equation of model 2 was obtained according to the regression results:

$Y=0.148+0.559 * \mathrm{X} 2-0.205 * \mathrm{X}_{3}+1.136 * \mathrm{X}_{4}+0.368 * \mathrm{X}_{5}-0.637 * \mathrm{X}_{6}+\varepsilon$

The equation can be seen, the shareholding ratio of each increase of $1 \%$, the underpricing rate will increase by $55.9 \%$, and the shareholding ratio of IP0 underpricing rate of $\mathrm{P}$ test value of 0.071 , indicating significant impact, which shows that the higher the proportion of VC/PE companies, IP0 underpricing rate is higher, does not conform to the assumptions of the 2 assumptions. Although there is no private equity investment support for the impact of IPO underpricing rate is not significant, but for companies with $\mathrm{VC} / \mathrm{PE}$ support, $\mathrm{VC} / \mathrm{PE}$ stake high proportion of enterprises, which shows that private equity investment institutions generally do not have a good ability to identify the project, the investment of the enterprise IPO cannot play a certification role, so that 2 does not set up.

\subsection{Hypothesis 3 Test}

According to the research hypothesis, hypothesis 3 is mainly to test the value added effect of private equity investment, and compared the enterprise without private equity investment support, on the GEM listed companies after the IPO market performance, whether private equity investment has a negative role. So in this paper, we choose the growth, profitability and operating capacity of three indicators to reflect the performance of its market.

According to the previous research methods, the test results of the hypothesis 3 , are shown in the following Table 10.

Table 10. Square Error Checking

\begin{tabular}{ccccc}
\hline & $\begin{array}{c}\text { Levene } \\
\text { Statistic }\end{array}$ & df1 & df2 & $\begin{array}{c}\text { Significa } \\
\text { nt }\end{array}$ \\
Fixed asset growth rate B & 1.886 & 1 & 150 & .173 \\
Total asset growth rate B & 1.211 & 1 & 150 & .663 \\
Net profit growth rate of B & 1.503 & 1 & 150 & .477 \\
Operating profit growth rate of & 1.131 & 1 & 150 & .721 \\
$\quad$ B & 1.423 & 1 & 150 & .524 \\
$\begin{array}{c}\text { Operating income growth rate } \\
\text { of B }\end{array}$ & & & & \\
Total assets net profit margin & 2.036 & 1 & 150 & .158 \\
$\quad$ (ROA) C & 3.273 & 1 & 150 & .075 \\
Return on net assets (ROE) & 1.8861 & 1 & 150 & .729 \\
\hline Turnover ratio of total assets & & & & \\
\hline
\end{tabular}

According to the test results in Table 10, we can find that all the significant is greater than 0.05 . Therefore, through the homogeneity test of variance, each index meets the premise of variance analysis. By means of comparison, we can find that after the listing, the enterprise with VC/PE support is inferior to the enterprises without VC/PE support in the profitability, growth and operational capacity. And and the difference between these enterprises in profitability is more significant. The $\mathrm{P}$ test values of total assets net profit margin (ROA) and net assets yield (ROE) were 0.031 and 0.030 . This shows that the enterprise with VC/PE support is inferior to the enterprise without VC/PE support in the performance after the listing. VC/PE does not play a role in the value added effect, and this difference is particularly significant in profitability, and the hypothesis 3 is established. 


\section{Conclusion}

According to the test results of hypothesis 1 and 2, the impact of private equity investment on IPO underpricing rate is not significant, that is to say, the phenomenon of high underpricing on the GEM market, while in the case of high underpricing rate, the higher the proportion of VC/PE companies, IPO underpricing rate is correspondingly higher, which is just the opposite of the assumption that 2 private equity investment on corporate certification regulatory effect is not significant. And on the assumption that the inspection found, listed on the first day turnover rate and listed on the first day of earnings and the issue price of IPO underpricing rate has a significant effect, indicating that influence enterprise IPO underpricing rate of the biggest factor is the secondary market to sought by enterprises and the investors' sentiment, investors of the gem excessive enthusiasm led to the IPO underpricing rate is generally high.

\section{References}

[1] Z. Xu, F. Zheng and J. Xing “The Impact of Private Equity on the Over-investment Behavior of Listed Companies: Evidence from Chinese GEM:, Journal of Finance \& Economics, (2015).

[2] H. W. Zhu, C. Chen and S. O. Economics, "Private Equity Investment and Corporate Governance:An Empirical Study Based on Listed Companies of GEM Board", Journal of Guangdong University of Finance \& Economics, (2014).

[3] W. He and Y. Liao, "Study of the Impact of Private Equity on the Listed Companies' Earnings Management", Open Cybernetics \& Systemics Journal, vol. 9, no. 1, (2015), pp. 845-850.

[4] Z. Wang, C. Y. Zhu and Y. Huang, "An empirical study on the impact of listed tourism companies' capital structure on Institutional Investors' Stockholding”, // Artificial Intelligence, Management Science and Electronic Commerce (AIMSEC), 2011 2nd International Conference on. IEEE, (2011), pp. 5393 - 5396.

[5] X. F. Zhou, "The Impact of Debt Financing on Non-efficient Investment-Based on an Empirical Study of Private Listed Companies in China", Journal of Jinan University, (2011).

[6] L. L. Suo and K. Z. Yang, "Empirical Study on Venture Investment and Earnings Management of IPO: Based on GEM Listed Companies", Journal of Nanjing Audit University, (2011).

[7] H. E. Yun-Qiang, Y. Liu and D. L. Jin, "The Profitability of Listed Companies on GEM Factors: An Empirical Study Based on Quantile Regression", Journal of Shijiazhuang University of Economics, (2014).

[8] Y. W. Deng, Z. Wang and X. Huang, "An empirical study on the impact of listed tourism companies TMT demographic characteristics on institutional investors' stockholding”, // Software Engineering and Service Science (ICSESS), 2011 IEEE 2nd International Conference on. IEEE, (2011), pp. 787-790.

[9] A. Seetharaman and J. R. Raj, "An Empirical Study on the Impact of Earnings per Share on Stock Prices of a Listed Bank in Malaysia”, International Journal of Applied Economics \& Finance, vol. 5, no. 2, (2011).

[10] M. Q. Deng, Y. Z. Wei and B. S, Xie, "An Empirical Study on Affecting Factors of the Information Disclosure Quality of GEM Listed Company", Science Technology \& Industry, (2015).

[11] W. U. Fang, W. Yan and X. Xing, "An Empirical Research on the Impact of Corporate Social Responsibility on Corporate Financial Performance of Pharmaceutical Companies”, Ecological Economy, (2015).

[12] A. F. A. A. El-Fakki and S. M. E. Hamad, "The Impact of the Application of Fair Value Accounting on the Quality of Accounting Information. An Empirical Study on a Group of Companies Listed on the Khartoum Stock Exchange", International Journal of Academic Research in Accounting Finance \& Management Sciences, vol. 5, (2015), pp.148-160.

[13] M. M. Munshi and S. K. Deshpande, "An Empirical Study on the Impact of Outbound Training on the Personality and Behavior of Management Students", Social Science Electronic Publishing, vol. 8, (2015).

[14] A. Alzeban, "The Impact of Culture on the Quality of Internal Audit: An Empirical Study", Journal of Accounting Auditing \& Finance, vol. 30, no. 1, (2015), pp. 57-77. 


\section{Authors}

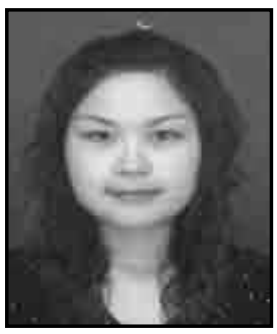

Yuanyuan Wang, Female, September 1, 1983, reading doctoral students; China, hunan; Intermediate engineer; Research interests: management science and engineering; Central south university, central south university in changsha yuelu district in hunan business school.

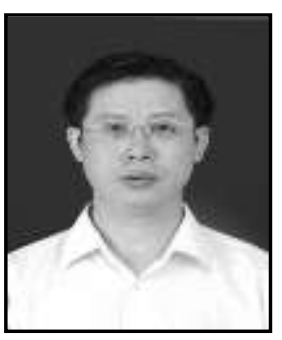

Jianhua Luo, Male, January 8, 1956, Dr, in China's hunan province, professor, research direction: industrial organization theory and the practice; Investment and financing decision making and management; Enterprise financing and credit management; Enterprise strategic management. Central south university; Hunan changsha yuelu district central south university business school. 
International Journal of u- and e- Service, Science and Technology

Vol. 10, No. 1 (2017) 